\title{
New Drugs and Emerging Therapeutic Targets in the Endothelin Signaling Pathway and Prospects for Personalized Precision Medicine
}

\author{
A. P. DAVENPORT ${ }^{1}$, R. E. KUC ${ }^{1}$, C. SOUTHAN ${ }^{2}$, J. J. MAGUIRE ${ }^{1}$ \\ ${ }^{1}$ Experimental Medicine and Immunotherapeutics, University of Cambridge, Addenbrooke's \\ Hospital, Cambridge, United Kingdom, ${ }^{2}$ Deanery of Biomedical Sciences, University of Edinburgh, \\ Edinburgh, United Kingdom
}

Received January 26, 2018

Accepted March 29, 2018

\section{Summary}

During the last thirty years since the discovery of endothelin-1, the therapeutic strategy that has evolved in the clinic, mainly in the treatment of pulmonary arterial hypertension, is to block the action of the peptide either at the $\mathrm{ET}_{\mathrm{A}}$ subtype or both receptors using orally active small molecule antagonists. Recently, there has been a rapid expansion in research targeting ET receptors using chemical entities other than small molecules, particularly monoclonal antibody antagonists and selective peptide agonists and antagonists. While usually sacrificing oral bio-availability, these compounds have other therapeutic advantages with the potential to considerably expand drug targets in the endothelin pathway and extend treatment to other pathophysiological conditions. Where the small molecule approach has been retained, a novel strategy to combine two vasoconstrictor targets, the angiotensin $\mathrm{AT}_{1}$ receptor as well as the $\mathrm{ET}_{\mathrm{A}}$ receptor in the dual antagonist sparsentan has been developed. A second emerging strategy is to combine drugs that have two different targets, the $\mathrm{ET}_{\mathrm{A}}$ antagonist ambrisentan with the phosphodiesterase inhibitor tadalafil, to improve the treatment of pulmonary arterial hypertension. The solving of the crystal structure of the $\mathrm{ET}_{\mathrm{B}}$ receptor has the potential to identify allosteric binding sites for novel ligands. A further key advance is the experimental validation of a single nucleotide polymorphism that has genome wide significance in five vascular diseases and that significantly increases the amount of big endothelin-1 precursor in the plasma. This observation provides a rationale for testing this single nucleotide polymorphism to stratify patients for allocation to treatment with endothelin agents and highlights the potential to use personalized precision medicine in the endothelin field.

\section{Key words}

Allosteric modulators - Biased signaling • G-protein coupled receptors • Endothelin-1 • Monoclonal antibodies • Pepducins • Single nucleotide polymorphisms

\section{Corresponding author}

A. P. Davenport, Experimental Medicine and Immunotherapeutics, University of Cambridge, Addenbrooke's Hospital, Cambridge, CB2 0QQ, United Kingdom. Fax: 01223 762576. E-mail: apd10@medschl.cam.ac.uk

\section{Introduction}

During the last thirty years since the discovery of endothelin-1 (ET-1), the therapeutic strategy that has evolved in the clinic, mainly in the treatment of pulmonary arterial hypertension (PAH), is to block the action of the peptide at the $\mathrm{ET}_{\mathrm{A}}$ subtype using ambrisentan (Letairis, Volibris, LU208075) or by blocking both receptors using bosentan (Tracleer, Ro47-0203) and macitentan (Opsumit, ACT-064992). All three drugs are orally active small molecule antagonists (Maguire and Davenport 2014). The timelines for key discoveries in the ET signaling pathway (the three ET peptides, two receptors and the endothelin converting enzymes (ECE), ECE-1 and ECE-2 are shown in Figure 1, together with the most widely used selective peptide ligands used to characterize the receptors in vitro and in vivo. 


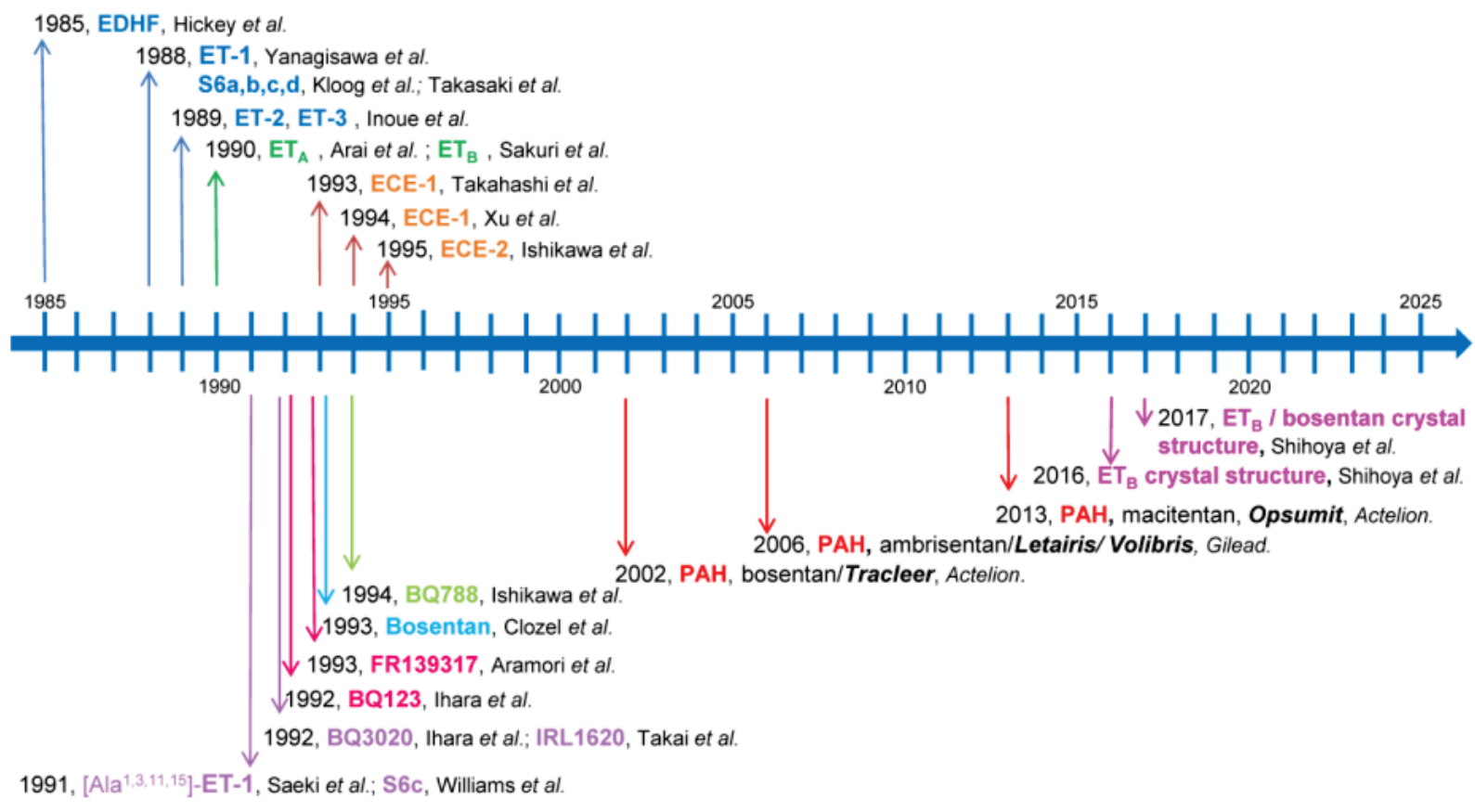

Fig. 1. The timelines for key discoveries in the $E T$ signaling pathway: the three $E T$ peptides, $E T_{A}$ and $E T_{B}$ receptors and endothelin converting enzymes, ECE-1 and ECE-2. The twenty-one amino acid sarafotoxins S6a, b, c, d, identified in the venom of the snake Atractaspis engaddensis that have a high degree of sequence similarity, are also shown. Timelines for the identification of key pharmaceutical agents are listed: $\mathrm{ET}_{\mathrm{B}}$ agonists $\left[\mathrm{Ala}^{1,3,11,15}\right]-\mathrm{ET}-1, \mathrm{BQ} 3020$ and sarafotoxin $\mathrm{S}^{\mathrm{C}} \mathrm{C} ; \mathrm{ET}_{\mathrm{A}}$ antagonists $\mathrm{BQ} 123$ and $\mathrm{FR} 139317$; bosentan, the first $\mathrm{ET}_{A} / E T_{B}$ antagonist approved for clinical use; $\mathrm{ET}_{\mathrm{B}}$ antagonist $\mathrm{BQ788;} \mathrm{ET}_{\mathrm{A}}$ antagonist ambrisentan; the next generation of $\mathrm{ET}_{\mathrm{A}} / \mathrm{ET}_{\mathrm{B}}$ antagonists, macitentan; the crystal structure of the $\mathrm{ET}_{\mathrm{B}}$ receptor.

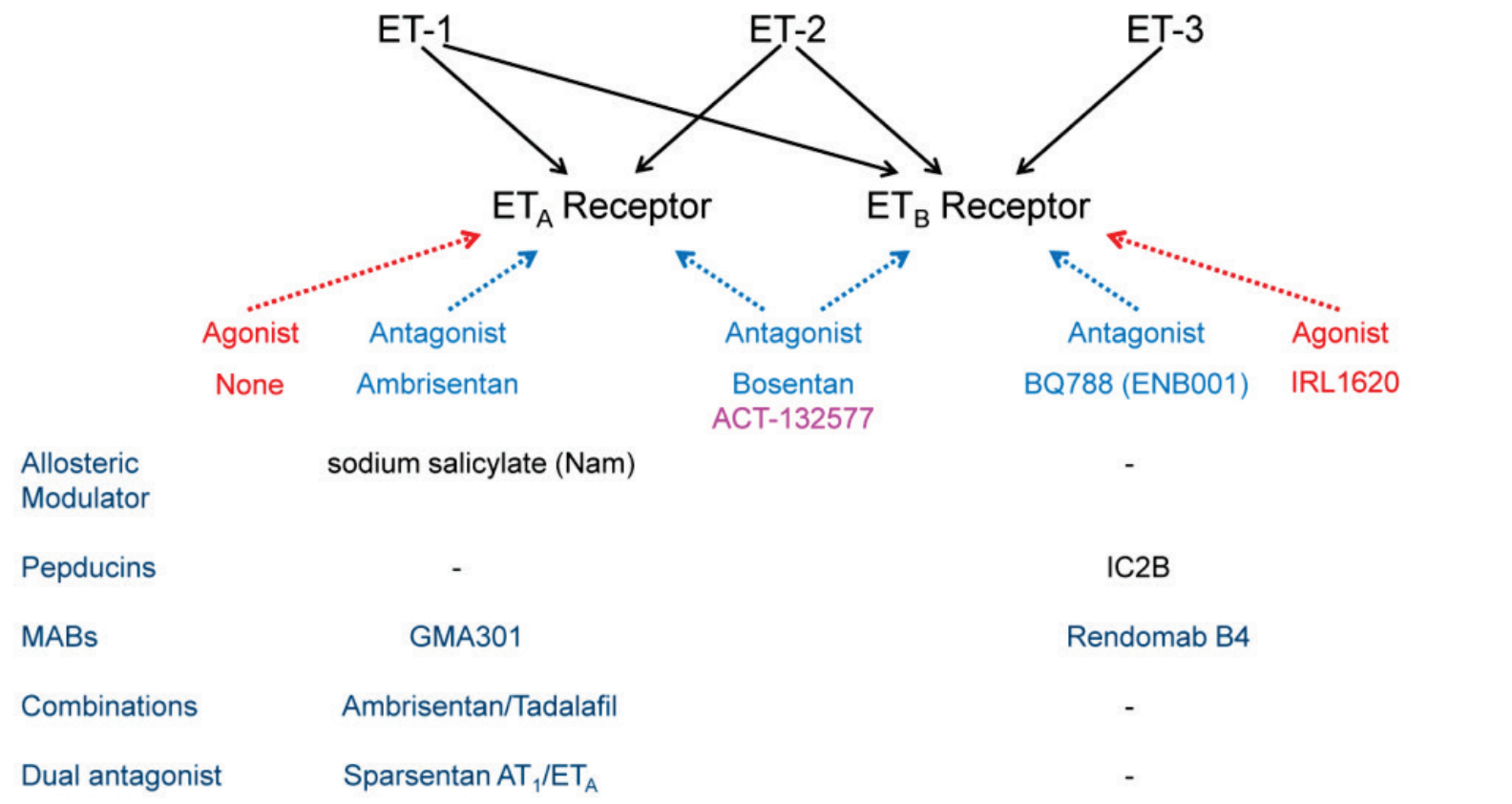

Fig. 2. ET signaling pathway, showing established and emerging pharmacological targets together with corresponding agents.

Recently, there has been a rapid expansion in research targeting ET receptors using chemical entities other than small molecules, namely monoclonal antibody antagonists and selective peptide agonists and antagonists (Fig. 2). While usually sacrificing oral bio-availability, these compounds have other therapeutic advantages with the potential to considerably expand drug targets in the ET pathway and extend treatment to other pathophysiological conditions. Where the small molecule approach has been retained, the novel strategy is to 
combine two vasoconstrictor targets, the angiotensin $\mathrm{AT}_{1}$ as well as the $\mathrm{ET}_{\mathrm{A}}$ receptors in a dual antagonist, sparsentan (Komers et al. 2017). A second emerging strategy is to use two separate drugs, the $\mathrm{ET}_{\mathrm{A}}$ antagonist ambrisentan with the phosphodiesterase (PDE) 5 inhibitor tadalafil, to improve the treatment of PAH (Galie et al. 2015) (Fig. 2). For endothelin research the most recent milestones in scientific progress are shown in Figure 1 culminating in the solving of the crystal structure of the $\mathrm{ET}_{\mathrm{B}}$ receptor that has the potential to identify allosteric binding sites for further novel ligands (Shihoya et al. 2016, Shihoya et al. 2017). Finally, a further key advance is the experimental validation of a single nucleotide polymorphism (SNP) that has genome wide significance in five vascular diseases that significantly increases the amount of big ET precursor in the plasma (Gupta et al. 2017). This study provides a rationale for testing for this SNP to stratify patients for allocation to treatment with ET compounds and demonstrates the potential for the use of precision medicine in the ET field. This review focusses on a concise update of drugs in the ET field and other reviews should be consulted for more details on ET signaling pathways (Davenport et al. 2016, Houde et al. 2016, Czopek et al. 2016).

\section{ET $_{B}$ peptide antagonist BQ788 (ENB001, ENB Therapeutics) in melanoma}

BQ-788 has been established as a highly selective peptide $\mathrm{ET}_{\mathrm{B}}$ antagonist both in vitro and in vivo in the clinic and is now being explored in a range of clinical conditions (Davenport et al. 2016). The ET signaling pathway has been implicated in a number of cancers. In particular, the $\mathrm{ET}_{\mathrm{B}}$ receptor is overexpressed in melanoma (Asundi et al. 2011), a cancer that develops from pigment-containing melanocytes where ET has a role in proliferation and melanin synthesis and typically occurs in the skin. It is an aggressive cancer, characterized by its capacity to metastasize, leading to an increase in mortality rates and affects about 340,000 patients in the US and Europe. The transformation of melanocytes to melanoma cells is often associated with an increased capacity to proliferate. It is thought that $\mathrm{ET}_{\mathrm{B}}$ receptors are a driver of melanoma progression and marker of aggressive phenotype (Bittner et al. 2000). BQ788 inhibits melanoma cell progression (Bagnato et al. 2004) and the growth of xenograft human melanoma tumors in mice which is thought to resemble spontaneous human melanoma regression (Lahav 2005). In a small clinical study, the local action of intra-lesion administration of $\mathrm{BQ}-788$ in five melanoma patients found that excised treated lesions exhibited decreased anti-apoptotic markers and $\mathrm{ET}_{\mathrm{B}}$ receptors compared with saline controls. In one patient, treated for longer than one week, lesion growth was inhibited (Wouters et al. 2015). In this setting BQ788 was tolerated. These results suggest that $\mathrm{ET}_{\mathrm{B}}$ receptors may play a key role in melanoma and represents a new therapeutic target.

The MAP-kinase (MAPK) pathway is deregulated in the majority of malignant melanomas but therapeutic targeting of the primary driver of hyper-active MAPK signaling, BRAF, while initially effective in patients, owing to patient heterogeneity can lead to resistance. ET-1 gene expression was found to be enhanced in tumors of patients on BRAF treatment and this was proposed as a mechanism of resistance. Treatment with bosentan overcomes the ET-1 signaling pathway and prolongs BRAF-inhibitor responses (Smith et al. 2017).

\section{Therapeutic monoclonal antibodies directed against the $\mathbf{E T}_{B}$ receptor: Rendomab-B1 and $B 4$}

Class A G-protein coupled receptors (GPCRs) that include the ET sub-types are targets of about one third of all current medicines used in the clinic. The development of monoclonal antibodies (MABs) has been a major growth area with over fifty approved for clinical use. In addition to being highly selective for the target protein, MABs can have less off-target actions. They have a very long plasma half-life compared with small molecules, leading to a prolonged time course of action of several months and to improved patient compliance. The majority of MABs to GPCRs tend to bind to extracellular regions and therefore can stabilize different conformational states compared with small molecule ligands that bind to transmembrane domains. MABs may cause an immunogenic response in human patients, reducing their therapeutic efficacy, but this can be mitigated by using human-derived sequences (Hutchings et al. 2017). The main disadvantage of MABs is that there can be significantly greater costs of manufacturing large proteins with post-translational modifications compared with small molecules and the need to penetrate tissues, for example, to reach cell surface expressed receptors. MABs potentially offer a wider range of therapeutic strategies compared with small molecules, 
particularly when the X-ray structure is known, as is the case of the $\mathrm{ET}_{\mathrm{B}}$ receptor, to discover regions distinct from the ligand binding site (allosteric modulators). MABs can bind and stabilize the inactive state of a receptor blocking any change in the conformational structure needed to activate intracellular transduction pathways.
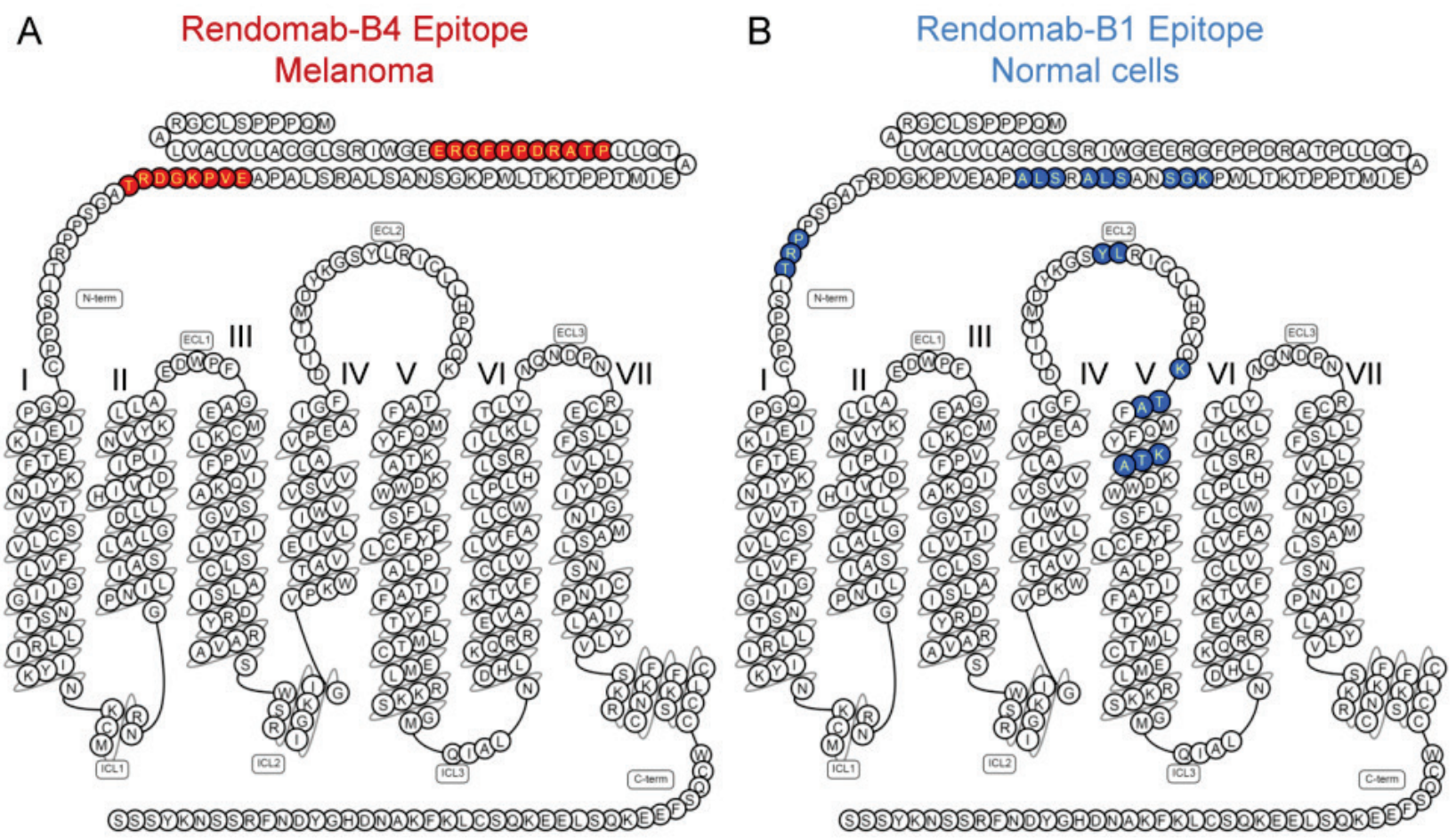

Fig. 3. Structure of the $E T_{B}$ receptor showing amino acids determined by epitope mapping interacting with the MAB Rendomab-B4 in melanoma (A) compared to Rendomab-B1 interacting with different regions with native $\mathrm{ET}_{\mathrm{B}}$ receptors (B). Roman numerals indicate the transmembrane spanning domains (Pándy-Szekeres et al. 2018).

The development of MABs to GPCRs has proved to be challenging. Recently, the first monoclonal antibody to be developed with sub-nanomolar affinity at the $\mathrm{ET}_{\mathrm{B}}$ receptor was reported. Rendomab-B1 was found to be more effective than BQ788 in competing for ET-1 at the $\mathrm{ET}_{\mathrm{B}}$ receptor and represents a significant advance for the ET field and GPCRs in general (Allard et al. 2013). Rendomab-B1 was proposed to function as an antagonist, based on the observed inhibition of ET-1induced $\mathrm{IP}_{3}$-calcium signaling. Epitope mapping suggested Rendomab-B1 recognized two discontinuous regions in the N-terminal extracellular domain and one in the extracellular loop E2 (Fig. 3).

Surprisingly when tested in melanoma cells, Rendomab-B1 had only low affinity for cell surface $\mathrm{ET}_{\mathrm{B}}$ receptors expressed in this cancer. This finding suggested structural heterogeneity among the $\mathrm{ET}_{\mathrm{B}}$ sub-type in tumors. The authors (Borrull et al. 2016) went on to discover a new MAB Rendomab-B4 that was able to bind to $\mathrm{ET}_{\mathrm{B}}$ receptors in three melanoma cell lines (UACC-257, WM-266-4 and SLM8). In one of these (UACC-257) Rendomab-B4 was internalized and found to co-localize with the early endosomal protein EEA-1. This is consistent with the known properties of $\mathrm{ET}_{\mathrm{B}}$ receptors being sorted from endosomes to lysosomes and degraded, resulting in signal termination. In contrast, $\mathrm{ET}_{\mathrm{A}}$ receptors are dephosphorylated in the endosomes and recycled back to the cell surface to signal again. Intriguingly, Rendomab-B4 behaved as a biased allosteric modulator able to inhibit $\mathrm{G}$ protein-dependent signaling (ET-mediated phospholipase C pathway) but was less effective at inhibiting the $\beta$-arrestin dependent pathway (ERK1/2 phosphorylation induced by ET).

Epitope mapping showed Rendomab-B4 recognizes two non-contiguous sequences in the $\mathrm{N}$-terminal of the receptor. Rendomab-B4 did not bind to $\mathrm{ET}_{\mathrm{B}}$ receptors expressed in HEK or native receptors in human umbilical vein endothelial cells. The binding properties were thus opposite to Rendomab-B1. Borrull et al. (2016) suggest possible explanations for these differences. The most plausible is that there could be differences in post-translational modifications, where $\mathrm{ET}_{\mathrm{B}}$ receptors have a surprising number (Davenport et al. 2016). The most likely is a potential glycosylation site at 
$\operatorname{Asn}^{59}\left(\mathrm{~N}^{59}\right)$ in the $\mathrm{N}$-terminus located between the two sequences that are thought to bind the MAB. However, there is no evidence yet that this is important for binding, although in other GPCRs at least one glycosylation site is often critical for receptor expression at the cell membrane and for function. Alternative splice variants have been identified encoding $\mathrm{ET}_{\mathrm{B}}$ receptors but to date when artificially expressed, display no change in binding characteristics and their physiological or pathophysiological significance remain unclear (Davenport and Maguire 2006). A detailed experimental study using three antisera site-directed to three different regions of the $\mathrm{ET}_{\mathrm{B}}$ receptor to ensure visualization of both wild type and splice variants found no differences in distribution in human kidney compared with $\mathrm{ET}_{\mathrm{B}}$ receptors visualized by autoradiography using radiolabeled $\mathrm{ET}_{\mathrm{B}}$ ligands (Kuc and Davenport 2004). Splice variants seem an unlikely reason for differences in these MABs. These MABs have not been tested in vivo and the pharmacokinetic properties are not yet known. Based on the published pharmacodynamics profile, Rendomab-B1 may mimic the action of the $\mathrm{ET}_{\mathrm{B}}$ antagonist $\mathrm{BQ788}$ to block endothelial $\mathrm{ET}_{\mathrm{B}}$ receptors, inhibiting autocrine-paracrine mediated release of endothelium derived relaxing factors and therefore cause vasoconstriction. In contrast, if the binding properties of Rendomab-B4 are retained in vivo, this $\mathrm{MAB}$ would be predicted to bind $\mathrm{ET}_{\mathrm{B}}$ receptors present on melanoma intra-cranially xenografted into mice but to have little or no effect on normal cells expressing $\mathrm{ET}_{\mathrm{B}}$ receptors and therefore provide an elegant strategy for selectively targeting tumors.

These studies provide proof of principle for the generation of a pharmacologically active MABs against the $\mathrm{ET}_{\mathrm{B}}$ receptor. This is important as MABs may be further engineered to extend therapeutic targets, particularly in cancer. For example, MABs can be conjugated to a chemotherapy drug or to a radioactive compound and this toxic payload may be used to selectively treat tumors in which $\mathrm{ET}_{\mathrm{B}}$ receptors are overexpressed. Bispecific MABs can also be developed that bind, for example, to $\mathrm{ET}_{\mathrm{B}}$ in target tumors and to $\mathrm{CD} 3$ expressed on $\mathrm{T}$ cells to promote the immune system to attack the cancer cells.

\section{Therapeutic monoclonal antibodies directed against the $\mathrm{ET}_{\mathrm{A}}$ receptor}

Antibodies have been generated to the $\mathrm{ET}_{\mathrm{A}}$ receptor but these have largely been restricted to immunohistochemical localization of the protein rather than directed to the development of MABs and exploring their pharmacological properties, particularly antagonism of ET-1 responses. Recently, preliminary data have been reported on Rendomab-A63 (Herbet et al. 2018), a MAB directed against the human $\mathrm{ET}_{\mathrm{A}}$ receptor that binds with sub-nanomolar affinity $\left(\mathrm{K}_{\mathrm{D}}\right.$ of $\left.0.3 \mathrm{nM}\right)$. A humanized $\mathrm{ET}_{\mathrm{A}} \mathrm{MAB}, \mathrm{GMA} 301$, has been reported in a patent and scheduled to be tested in a clinical trial by Gmaxbiopharm but no further information is available as a publication (http://www.gmaxbiopharm.com/ pipeline3.html). An $\mathrm{ET}_{\mathrm{A}}$ selective small molecule or peptide analogue has not been discovered and an $\mathrm{ET}_{\mathrm{A}} \mathrm{MAB}$ agonist could be exploited as a tool compound for further exploration of the pharmacology of this sub-type. To date it has been assumed that because of $\mathrm{ET}_{\mathrm{A}}$ mediated vasoconstriction, a selective $\mathrm{ET}_{\mathrm{A}} \mathrm{MAB}$ agonist would not have a therapeutic application. However, as discussed later, Gupta et al. (2017) identified vascular diseases such as migraine headache, where elevated ET-1 levels associated with the minor allele $\mathrm{G} / \mathrm{G}$ may be beneficial in preventing the condition, suggesting a possible but highly speculative application for a selective $\mathrm{ET}_{\mathrm{A}} \mathrm{MAB}$ agonist in individuals with the $\mathrm{A} / \mathrm{A}$ allele and therefore lower ET-1 levels in the plasma. Conversely, some insight into the potentially deleterious actions of an $\mathrm{ET}_{\mathrm{A}} \mathrm{MAB}$ agonist is provided by the identification of autoantibodies to the $\mathrm{ET}_{\mathrm{A}}$ receptor. In one study, in most patients with systemic sclerosis, in which augmented ET signaling has been implicated, $\mathrm{ET}_{\mathrm{A}}$ receptor autoantibodies were detected and were functionally active, that is acted as agonists. Surprisingly, the author reported autoantibodies specifically bound to endothelial cells although these cells are widely considered to express $\mathrm{ET}_{\mathrm{B}}$ but not $\mathrm{ET}_{\mathrm{A}}$ (Riemekasten et al. 2011).

ET-1 remains one of the most potent vasoconstrictors identified, with a usually long lasting action, so $\mathrm{ET}_{\mathrm{A}}$ receptor $\mathrm{MABs}$ may be an attractive therapeutic strategy if they display very long half-lives compared with small molecule antagonists. It has been suggested that the long lasting action of ET-1 is the result of irreversible binding to $\mathrm{ET}_{\mathrm{A}}$ receptors. However, dissociation of labelled ET-1 from cloned $\mathrm{ET}_{\mathrm{A}}$ receptors was found to be slower compared with other vasoactive agents but was not irreversible (Blandin et al. 2000) with about a fifth of specific $\left[{ }^{125} \mathrm{I}\right]-\mathrm{ET}-1$ binding dissociated from native $\mathrm{ET}_{\mathrm{A}}$ receptors human vessels after $20 \mathrm{~min}$ (Maguire et al. 1996). However, it is crucial that MABs 
are able to reverse established ET-1 constrictor responses in pathophysiological conditions such as cerebral vasospasm. Long lasting ET-1 constrictor responses have been shown to be reversible by small molecule antagonists in vitro and in vivo (Warner et al. 1994, Pierre and Davenport 1999).

\section{ET $_{B}$ agonists: IRL1620 (PMZ-1620, SPI-1620) in stroke, Alzheimer's disease and cancer}

High densities of $\mathrm{ET}_{\mathrm{B}}$ receptors are expressed in human brain $(\sim 90 \%$ in areas such as cerebral cortex) (Harland et al. 1998). IRL1620 [N-Succinyl-[Glu? $\mathrm{Ala}^{11,15}$ ] endothelin-1] was synthesized as an analogue of ET-1 and found to be highly selective for the $\mathrm{ET}_{\mathrm{B}}$ receptor (Takai et al. 1992). Although the $\mathrm{N}$-terminus incorporates an N-Succinyl modification to reduce metabolism by non-specific peptidases, plasma half-life is short (only a few minutes) and as a modified peptide it is not orally active and requires administration by injection. Despite this unpromising profile, this compound, known as PMZ-1620, is being explored in a number of diseases associated with the CNS in animal models and in clinical studies (Gulati 2016, Gulati et al. 2017, Joshi et al. 2016, Briyal et al. 2015). The therapeutic strategy is to exploit the IRL-1620 induced vasodilatation and neuroprotection mediated by the $\mathrm{ET}_{\mathrm{B}}$ receptor. For example in a rat model of focal ischemic stroke (permanent middle cerebral artery occlusion), intravenous injections of IRL1620 post occlusion reduced infarct volume, reduced oxidative stress and apoptosis but at the same time enhanced neuroregeneration via neurogenic and angiogenic growth factors (Leonard et al. 2011, Leonard et al. 2012, Leonard et al. 2013). Similarly in a rat model of Alzheimer's disease (amyloid peptide A $\beta 1-40$ administered into the intracerebral vessels), IRL1620 improved learning and memory (Briyal et al. 2014). The molecular mechanism is unclear but ECE-1 is thought to degrade amyloid $\beta$-peptides. Reduction in ECE activity leads to intracellular accumulation of amyloid $\beta$-peptide, linked to neurotoxicity in the early progression of Alzheimer's disease (Eckman et al. 2001, Eckman et al. 2003, Eckman et al. 2006, Pacheco-Quinto and Eckman 2013).

In cancer, animal studies suggested that IRL1620 improved the efficacy of cancer agents such as doxorubicin and 5-flurouracil by causing vasodilatation thus increasing the amount of drug in tumors and therefore improving efficacy for a given dose (Maguire and Davenport 2014). Thus far however, these promising results have not been replicated in the clinic. In a multicenter, open-label Phase 2 study of a combination of IRL1620 (called SPI-1620) with docetaxel as secondline advanced biliary tract cancer for patients with advanced biliary tract cancer the pre-specified primary end point of progression free survival of 5 months or longer was not met (Kim et al. 2017).

\section{Repurposing the macitentan metabolite, ACT-132577}

Macitentan is metabolized to an active metabolite, ACT-132577. Although it has a lower potency than the parent compound, ACT-132577 reaches a higher plasma concentration after $30 \mathrm{~h}$ and has a longer half-life $(\sim 48 \mathrm{~h})$ than macitentan (Iglarz et al. 2008, Sidharta et al. 2011). ACT-132577 is being tested in a Phase 2 clinical trial for the treatment of hypertension.

\section{Dual $\mathrm{AT}_{1} / \mathrm{ET}_{\mathrm{A}}$ receptor antagonist, sparsentan}

Preclinical studies have shown that combination of antagonists blocking both angiotensin $\mathrm{AT}_{1}$ and $\mathrm{ET}_{\mathrm{A}}$ receptors caused a greater reduction in blood pressure in animal models of hypertension than blocking $\mathrm{AT}_{1}$ receptors alone. These results suggested a new therapeutic strategy of combing both actions in one molecule. Sparsentan (BMS-346567) is a first-in-class, orally active, antagonist that combines key $\mathrm{AT}_{1}$ and $\mathrm{ET}_{\mathrm{A}}$ receptor blocking moieties in the same compound. $\mathrm{AT}_{1}$ and $\mathrm{ET}_{\mathrm{A}}$ receptor interactions share a number of structural and functional similarities. It was developed by elegantly merging the structural elements present in an $\mathrm{AT}_{1}$ receptor antagonist irbesartan with structural elements in a biphenylsulfonamide $\mathrm{ET}_{\mathrm{A}}$ receptor antagonist.

Sparsentan has similar high affinity at both receptors: $0.8 \mathrm{nM}$ for $\mathrm{AT}_{1}$ and $9.3 \mathrm{nM}$ at $\mathrm{ET}_{\mathrm{A}}$. In preclinical studies in rats, the compound reduced blood pressure elevations caused by intravenous infusion of angiotensin II or big ET-1 to a greater extent and with longer duration than $\mathrm{AT}_{1}$ and $\mathrm{ET}_{\mathrm{A}}$ receptor antagonists alone. Using telemetrized spontaneously hypertensive rats, sparsentan was more effective than irbesartan. Sparsentan is being evaluated in Phase 2 trials for the treatment of focal segmental glomerulosclerosis, a cause of nephrotic syndrome in children and a major cause of adult renal failure. The pre-clinical studies suggested that 
sparsentan is effectively blocking the direct vascular actions of two potent constrictors peptides but it is not yet clear whether there are also effects on the downstream signaling pathways and on cell proliferation (Murugesan et al. 2005). Clinically, a further benefit of sparsentan is that patient compliance may be improved. However, it is not clear whether sparsentan has the same or reduced side effects associated with $\mathrm{ET}_{\mathrm{A}}$ antagonists (Komers et al. 2017).

\section{Combination therapy with ET $_{\mathrm{A}}$ antagonists and PDE5 inhibitors}

ET is continuously released from endothelial cells via the constitutive pathway and at low physiological concentrations interacts with endothelial $\mathrm{ET}_{\mathrm{B}}$ receptors in an autocrine or paracrine manner to released vasodilators such as nitric oxide, although prostacyclin or endothelium derive hyperpolarizing factor may also be released depending on the vascular bed. As the concentration increases, ET-1 interacts with mainly $\mathrm{ET}_{\mathrm{A}}$ receptors on smooth muscle cells to cause vasoconstriction. In addition, endothelial $\mathrm{ET}_{\mathrm{B}}$ activation internalizes the ligand-receptor complex and removes ET-1 from the circulation (Gasic et al. 1992, Fukuroda et al. 1994, Johnstrom et al. 2005). As a result, combined $\mathrm{ET}_{\mathrm{A}} / \mathrm{ET}_{\mathrm{B}}$ blockade results in a significant rise in circulating ET-1 whereas no increase occurs with selective $\mathrm{ET}_{\mathrm{A}}$ antagonism (Plumpton et al. 1996). Currently, it is not known what happens to plasma ET levels after suddenly withdrawing bosentan where both receptors are blocked whether this leads to a 'rebound' effect.

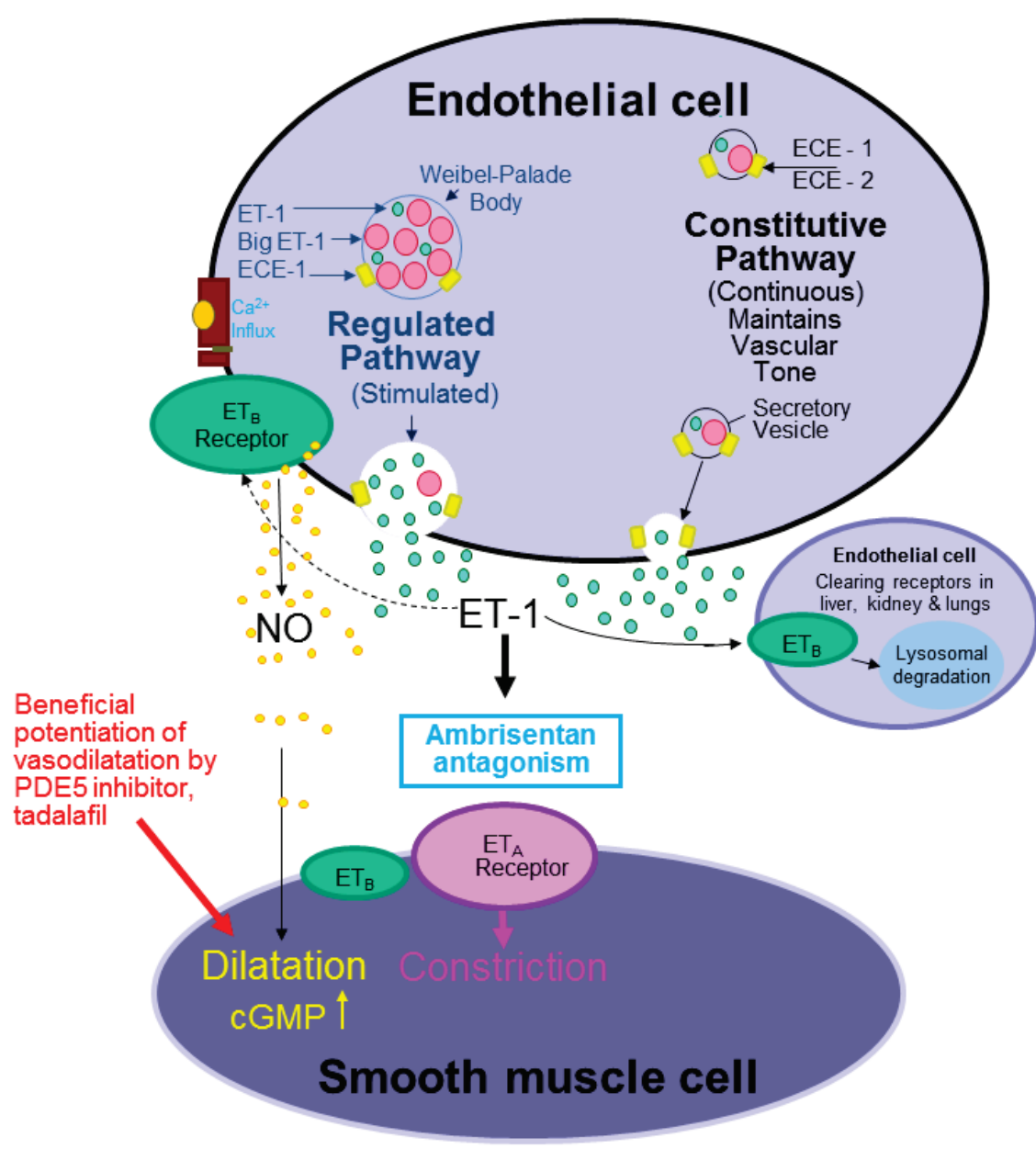

Fig. 4. Schematic diagram of the modulation of the ET-1 pathway in the vasculature of the lungs by combining ambrisentan with tadalafil. ET-1 is synthesized within the secretory vesicles of the constitutive pathway and is continuously released towards $\mathrm{ET}_{\mathrm{A}}$ receptors expressed by smooth muscle cells. ET-1 may also be released from the regulated pathway and released in response to external stimuli (Russell et al. 1998, Russell et al. 1999). ET-1 is increased in PAH and ambrisentan blocks increased signaling at $\mathrm{ET}_{\mathrm{A}}$ receptors but spares the beneficial $\mathrm{ET}_{B}$ clearing receptors that are expressed on endothelial cells and remove increased circulating peptide, particularly in the liver, kidney and lungs. It is hypothesized that tadalafil inhibits the breakdown of cGMP in smooth muscle to enhance the action of ET-1 acting in an autocrine/paracrine manner to release endothelium derived vasodilator, nitric oxide (NO) via endothelial $\mathrm{ET}_{\mathrm{B}}$ activation.

To date monotherapy using ET receptor antagonists or PDE5 inhibitors has been the initial treatment regime for patients with PAH (Kuntz et al. 2016). A number of preclinical studies suggested that combinations of the two compound would be beneficial. For example, Liang et al. (2012) found that the $\mathrm{ET}_{\mathrm{A}}$ selective antagonist ambrisentan and the PDE5 inhibitor tadalafil acted synergistically to relax ET-1 
constricted isolated pulmonary arteries from rats. Crucially, denudation of the endothelium from vessel rings abolished the vasodilator response to tadalafil and the synergistic vasorelaxant effect of tadalafil with ambrisentan. This synergism was not seen with mixed antagonists bosentan and macitentan, suggesting $\mathrm{ET}_{\mathrm{B}}$ receptors in the endothelium are necessary to enable a synergistic vasorelaxant effect of the drug combination. The potential molecular mechanism is shown in Figure 4. These results have translated into the clinic. A major study enrolled 500 newly diagnosed, treatment-naive patients with 253 assigned to the combination therapy and 126 and 121, respectively, to the ambrisentan and tadalafil monotherapy groups (Galie et al. 2015, Hoeper et al. 2016). Combination therapy resulted in a significantly lower risk of clinical-failure events (including hospitalization, disease progression and mortality) than the risk with ambrisentan or tadalafil. As might be expected, unwanted side-effect (headache and nasal congestion) thought to be associated with activation of $\mathrm{ET}_{\mathrm{B}}$ receptors occurred more frequently in combination-therapy. A retrospective analysis in a small number of patients supported these finding (Mercurio et al. 2018).

\section{Pepducins (cell penetrating peptides) directed against the $\mathrm{ET}_{\mathrm{B}}$ receptor}

Pepducins are synthetic peptides usually based on amino acid sequences of the three intracellular loops or the intracellular C-terminal tail of the GPCR (Carr and Benovic 2016, Tressel et al. 2011). The N-terminal is lipidated to aid transversing the cell membrane and anchor the peptide. Unlike small molecule ligands that tend to interact with extracellular loops and N-terminus that form the binding pocket, pepducins stabilize the target receptor in conformations that may stimulate or inhibit intracellular signaling. The main advantages of pepducins as drugs are likely to be similar to other ET peptide ligands of high specificity and selectivity but also the same disadvantages of not having oral bioavailability and potentially causing an immune response.

To date, pepducins have been used as tool compounds functioning as agonist or antagonists against a number of GPCRs but recently the first human clinical studies have been carried out using a pepducin targeting protease-activated receptor- 1 and was found to have the anticipated antiplatelet action with no reported adverse action (Gurbel et al. 2016).

A cell penetrating peptide has been identified, IC2B, that was generated as the name suggest to the amino acid sequences of the $\mathrm{ET}_{\mathrm{B}}$ second intracellular loop. In a rat model of hypoxia induced pulmonary hypertension, IC2B reduced pulmonary arterial pressure, right ventricular hypertrophy and pulmonary vascular remodeling without an effect on blood pressure, demonstrating efficacy in vivo. Interestingly, there was no evidence of hepatic toxicity that is a feature of the mixed antagonist bosentan. In acute studies, after $24 \mathrm{~h}$ of hypoxia, pulmonary arteries treatment with IC2B resulted in marked reductions in Akt and ERK activation, key kinases in vascular hypertrophy that are upregulated in this model. Immunofluorescent studies showed that IC2B mainly penetrated cells in the vascular media (where this sub-type, at least in rats, may mediate cell proliferation), implying little or no interaction with the endothelium but the explanation for this selectivity is not yet known. The authors suggested a mechanism of action whereby selective blockade of smooth muscle $\mathrm{ET}_{\mathrm{B}}$ receptor mediated vasoconstriction and proliferation via Akt and ERK signaling that contribute to disease progression, leaving endothelial $\mathrm{ET}_{\mathrm{B}}$ mediated vasodilatation, for example, unaffected. This speculation has not been confirmed and further studies have not been reported (Green et al. 2013). However, the study provides some preliminary evidence for the efficacy of pepducins to modulate the action of $\mathrm{ET}_{\mathrm{B}}$ receptors that appears effective in vivo.

\section{X-ray structures of endothelin $\mathbf{E T}_{B}$ receptor and allosteric modulators}

To date, less than 20 structures of Family A GPCRs have been solved experimentally and for small peptide ligands these are limited to receptors activated by shorter peptides, for example the thirteen amino acid peptide neurotensin. For the $\mathrm{ET}_{\mathrm{B}}$ receptor, the authors reported the structure in both ligand-free form and in complex with ET-1 (Shihoya et al. 2016). Interestingly, the larger twenty one amino acid peptide demonstrates interaction over a substantial portion of the molecule. A thermostabilized receptor was used containing five mutations in order to achieve crystallization. Importantly, the receptor still retained binding affinities for $\left[{ }^{125} \mathrm{I}\right]-\mathrm{ET}-1$ measured by saturation binding, comparable to values obtained in a range of native human receptors (Davenport 2002). Native $\mathrm{ET}_{\mathrm{B}}$ receptors display the same 
affinity for ET-1 and ET-3. However, the authors found that the combination of these mutations resulted in an order of magnitude decrease in affinity for ET-3 (in a competitive binding assay with $\left.{ }^{[255}\right] \mathrm{ET}-1$ ), but retained high affinity for ET-1. One of the mutations was Lys ${ }^{182}$, that had previously been shown by Lee et al. (1994) to not alter ET-1 binding, but unexpectedly affinities for ET-2, ET-3 and the $\mathrm{ET}_{\mathrm{B}}$ agonist sarafotoxin $6 \mathrm{C}$ were between one and three orders of magnitude lower than their corresponding wild-type values. These results suggest this residue is particularly important for ET-1 binding over the other isoforms. The crystal structure supports the hypothesis that tight associations of ETs with $\mathrm{ET}_{\mathrm{B}}$ receptors are mainly mediated through the $\alpha$-helical and $\mathrm{C}$-terminal regions, whereas the $\mathrm{N}$-terminal region which varies by two (ET-2) and four amino acids (ET-3) modulates selectivity. The $\mathrm{N}$-terminal region stabilizes the overall peptide architecture and thereby facilitates interactions with the receptor, the stabilizing effect of the N-terminal region is weaker in ET-3 owing to the bulky residues.

Over 20 amino acids in the $\mathrm{ET}_{\mathrm{B}}$ receptor were identified and proposed to interact with specific residues of ET-1. All of the residues except for one, $\mathrm{K}^{270}$, are conserved in both $\mathrm{ET}_{\mathrm{A}}$ and $\mathrm{ET}_{\mathrm{B}}$ receptors. This suggests that mutations of these residues can alter ET-1 and ET-3 binding to different degrees and the slightly different binding properties of the residues within the peptide ligands results in the lower affinity for the ET-3 at the thermostabilized receptor compared with the wild type. The authors proposed a model whereby transmembrane helices one, two, six and seven move and envelop the entire endothelin peptide, to form a lid-like architecture that covers the orthosteric pocket, predicted to form a very stable complex. This provides one structural explanation for the unusual property of ET-1 in causing long lasting responses and with a slow dissociation rate from the receptor (Shihoya et al. 2016).

Shihoya et al. (2017) extended these studies reporting the crystal structure of human $\mathrm{ET}_{\mathrm{B}}$ receptor bound to bosentan, the first ET antagonist to be approved for clinical use although it has a comparatively low affinity for native human receptors (Maguire et al. 2012). A high affinity $\mathrm{ET}_{\mathrm{B}}$-selective antagonist $\mathrm{K}-8794$ (Sawaki et al. 2000) was also co-crystalized. Bosentan is similar to K-8794 except for an ethylene glycol at the 6-position of the central pyrimidine template. Both compounds superimposed well to the receptor structure and the deduced binding was similar. The results were intriguing.

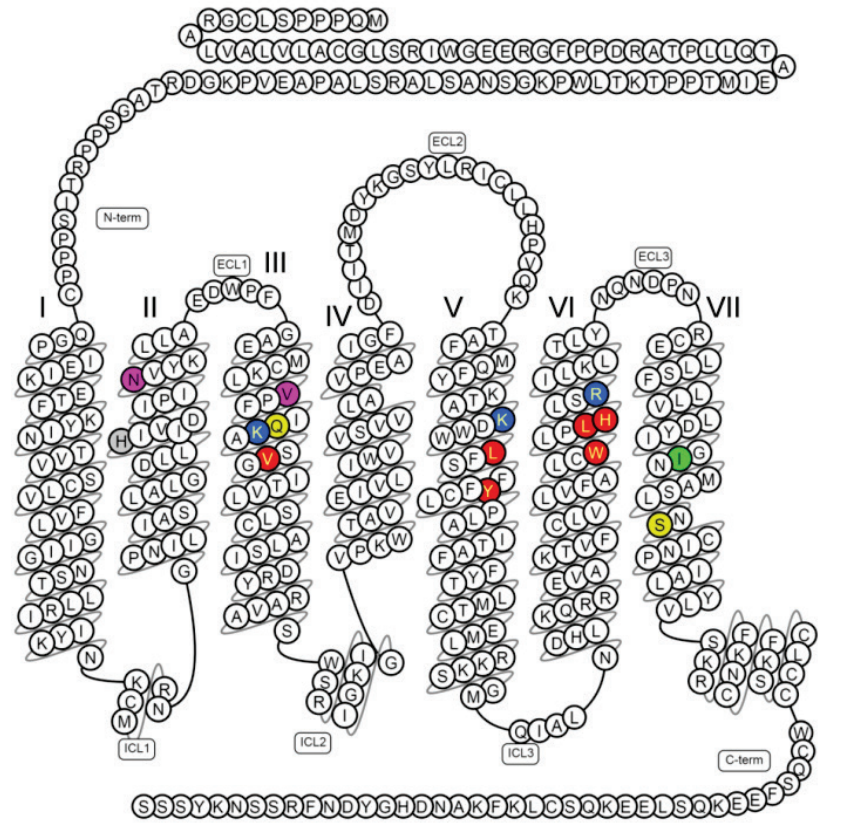

Fig. 5. Amino acids predicted from the crystal structure of the $\mathrm{ET}_{\mathrm{B}}$ receptor to interact with the $\mathrm{ET}_{\mathrm{B}}$ antagonist K-8794. Roman numerals indicate the transmembrane spanning domains. Ionic interaction of the sulfonamide of K-8794 with amino acids are shown in blue; the 4-t-butyl phenyl group linked to the sulfonamide forms hydrophobic contacts shown in turquoise; the methoxyphenoxy group of $\mathrm{K}-8794$ fits within the hydrophobic pocket formed by amino acids in red; the pyrimidine at the 2-position of the central pyrimidine forms a hydrophobic contact with $\mathrm{Ile}^{372}$ (green). The dimethylphenyl group makes van der Waals interactions with the side chains of $\mathrm{Asn}^{158}$ and $\mathrm{Val}^{177}$ (purple). The carbonyl oxygen of the amide bond forms a hydrogen bond with $\mathrm{His}^{150}$ grey and water-mediated hydrogen bonds with $\mathrm{Gln}^{181}$ and $\mathrm{Ser}^{379}$ (yellow) (Pándy-Szekeres et al. 2018).

K-8794 interactions were observed between its four substituents and seventeen amino acids in the receptor (Fig. 5). Seven were amino acids associated with mutations: $\mathrm{His}^{150}$ (TM2), $\mathrm{Gln}^{181}, \mathrm{Val}^{185}$ (TM3), $\mathrm{Leu}^{277}$ (TM5), $\operatorname{Trp}^{336}$, Leu ${ }^{339}, \mathrm{Arg}^{343}$ (TM6).

Bosentan occupied the bottom of the orthosteric site of the $\mathrm{ET}_{\mathrm{B}}$ receptor; although bosentan was discovered by screening rather than by rational design based on peptide structure, this corresponded to the binding site for the C-terminal tripeptide of ET-1 ( $\mathrm{Ile}^{19}, \mathrm{Ile}^{20}$, and $\left.\mathrm{Tr}^{21}\right)$. This suggests ionic and hydrophobic interactions between bosentan and C-terminal tripeptides of ET-1 within receptor are similar and are critical for both agonist and antagonist binding. The authors proposed that despite this similarity bosentan sterically prevents the inward movement of transmembrane helix six, blocking the action of ET-1. Since bosentan displays virtually the same affinity for the $\mathrm{ET}_{\mathrm{A}}$ receptor, it is likely this mechanism of action is also conserved in this sub-type. In contrast to ET-1, where 
binding induces a lid-like architecture that covers the orthosteric pocket to reduce dissociation, the bosentan binding site is open toward the extracellular solvent in agreement with the fast dissociation kinetics. The clinical use of bosentan, a surmountable reversible antagonist, is being superseded by macitentan, designed to have improved efficacy and optimized for potency and selectivity in structure-activity studies. Macitentan is an insurmountable antagonist and an order of magnitude more potent than bosentan as a result of longer receptor occupancy (seventeen minutes versus seventy seconds for bosentan measured by in vitro assays) (Iglarz et al. 2008, Sidharta et al. 2014, Clozel 2016). It is interesting to speculate whether the slower dissociation of macitentan is the result of better mimicry of the C-terminal tripeptide of ET-1 inducing the lid-like structure of the native peptide. The X-ray structure should foster a better understanding of structure activity with macitetan and the allosteric modulators (Talbodec et al. 2000).

\section{Why have no $\operatorname{ET}_{\mathrm{A}}$ selective agonists been discovered?}

The final missing reagent in the pharmacologist's armamentarium is an $\mathrm{ET}_{\mathrm{A}}$ selective agonist. The conniption between the relative merits of blocking only $\mathrm{ET}_{\mathrm{A}}$ versus blocking both subtypes continues but it has been generally accepted that most of the effects of $\mathrm{ET}_{\mathrm{A}}$ activation in pathophysiological conditions to cause, for example, vasoconstriction are deleterious. Therefore there has been no compelling evidence for activating the ET-1/ET $\mathrm{A}$ pathway. However, the identification of the SNP associated with vascular diseases where higher levels of ET-1 may be beneficial such as migraine headache may provide the stimulus to search for tool compounds.

\section{Biased signaling in the ET pathway}

Biased agonism (also known as biased signaling, ligand bias) is an emerging pharmacological paradigm with the potential to dramatically increase the therapeutic targeting of ET receptors. In addition to activating the G-protein pathway, ligands such as ET-1 activate the $\beta$-arrestin pathway which can lead to desensitization, receptor internalization and 'silencing' of the pathway. In other GPCR families it is clear that ligands can be designed to selectively activate the G-protein pathway over $\beta$-arrestin or vice versa.
In the CNS, TRV130, an agonist biased toward the G-protein pathway at the $\mu$-opioid receptor was found to display desirable analgesic actions but fewer of the unwanted side effects in the gastrointestinal tract and respiratory suppression compared to morphine (Singla et al. 2017). In the periphery, apelin receptor agonists biased to the G-protein pathway produce the desirable vasodilatation and inotropic action with expected reduced desensitization in volunteers and animal models (Brame et al. 2015, Reed et al. 2106). Apelin receptor ligands are downregulated in human pulmonary arterial hypertension and animal models (Yang et al. 2017a). Exogenous application of biased ligands to replace the missing peptides attenuates the development of the disease (Yang et al. 2017b). Conversely, the $\beta$-agonist carvedilol has been proposed as a $\beta$-arrestin biased ligand, beneficially and selectively activating this pathway compared to a balanced compound (Wang et al. 2017), although it should be noted there may also be a significant contribution from $\alpha 1$-adrenoreceptor antagonism. While both ET receptors are internalized by $\beta$-arrestin and dynamin/clathrin-dependent mechanisms, $\mathrm{ET}_{\mathrm{A}}$ are recycled to the plasma membrane for further signaling while $\mathrm{ET}_{\mathrm{B}}$ are targeted to lysosomes and degraded (Bremnes et al. 2000). Interestingly, increasing evidence shows that ET receptor/ $\beta$-arrestin signaling is dysregulated in ovarian cancer (Rosanò and Bagnato 2016a,b, Rosanò et al. 2014, Maguire and Davenport 2015) $\beta$-arrestin is required for ET-1-induced NF- $\kappa B$ activation (Cianfrocca et al. 2014). These studies suggest that the development of antagonists selectively blocking the ET-1/ $\beta$-arrestin pathway could be a new strategy. Although bosentan was the first mixed antagonist to enter the clinic to treat $\mathrm{PAH}$, it displays little selectivity for $\mathrm{ET}_{\mathrm{A}}$ over $\mathrm{ET}_{\mathrm{B}}$ receptors in radioligand binding (Maguire and Davenport 2014) and G-protein functional assays and has surprisingly low potency in vasoconstrictor assays $\left(K_{B}=1-3 \mu \mathrm{M}\right.$, Maguire et al. 2012). However, it was found to be a highly effective inhibitor of $\beta$-arrestin recruitment mediated by $\mathrm{ET}_{\mathrm{A}}$ compared to the $\mathrm{ET}_{\mathrm{B}}$ receptor (Maguire et al. 2012, Maguire 2016). Since some of the deleterious action of ET-1, at least in ovarian cancer, may be mediated by the $\beta$-arrestin pathway, similar biased antagonists may block the cancerous action of ET-1 but preserve beneficial G-protein mediated actions. 


\section{Prospects for personalized precision medicine in endothelin}

The goal of personalized medicine is to customize drug treatment for an individual patient. This can be achieved by linking variation in the patients genetics, such as a single nucleotide polymorphism (SNP, where a DNA sequence variation occurring when a single nucleotide in the genome differs between individuals) with a drug target such as a transmitter system suspected of causing the disease. Ideally such SNPs will occur in a large population which have very high genome wide association with a specific disease. These SNPs are common and replicated in a number of populations of different ethnicities. Recently Gupta et al. (2017) have identified rs9349379, a common A/G SNP in the third intron of the Phosphatase And Actin Regulator 1 (PHACTR1) gene, that has a key role in tubule formation and in endothelial cell survival but also regulates expression of the gene encoding ET-1, EDN1, located
$600 \mathrm{~kb}$ upstream. The authors found rs9349379 had the strongest association with coronary artery disease and coronary calcification for a single variant, and this far exceeded the association for the next most highly associated SNP, rs78145402. A high genome wide significant correlation with linked vascular conditions ischemic or coronary artery disease leading to atherosclerosis and angina (causing chest pain as a result of constricting coronary arteries) was also found in UK Biobank ( 400,000 individuals, Fig. 6, Sudlow et al. 2015).

Targeted deletion of a small region of the apparent regulatory DNA at rs9349379 element increased ET-1 gene and protein expression in endothelial cells and to a lesser extent in vascular smooth muscle cells. Gupta et al. (2017) tested the hypothesis that big ET-1 levels would be higher in individuals with the minor allele $(\mathrm{G} / \mathrm{G})$, intermediate levels in those with $\mathrm{A} / \mathrm{G}$ and lowest level in those with $\mathrm{A} / \mathrm{A}$ at rs9349379. In thirty three

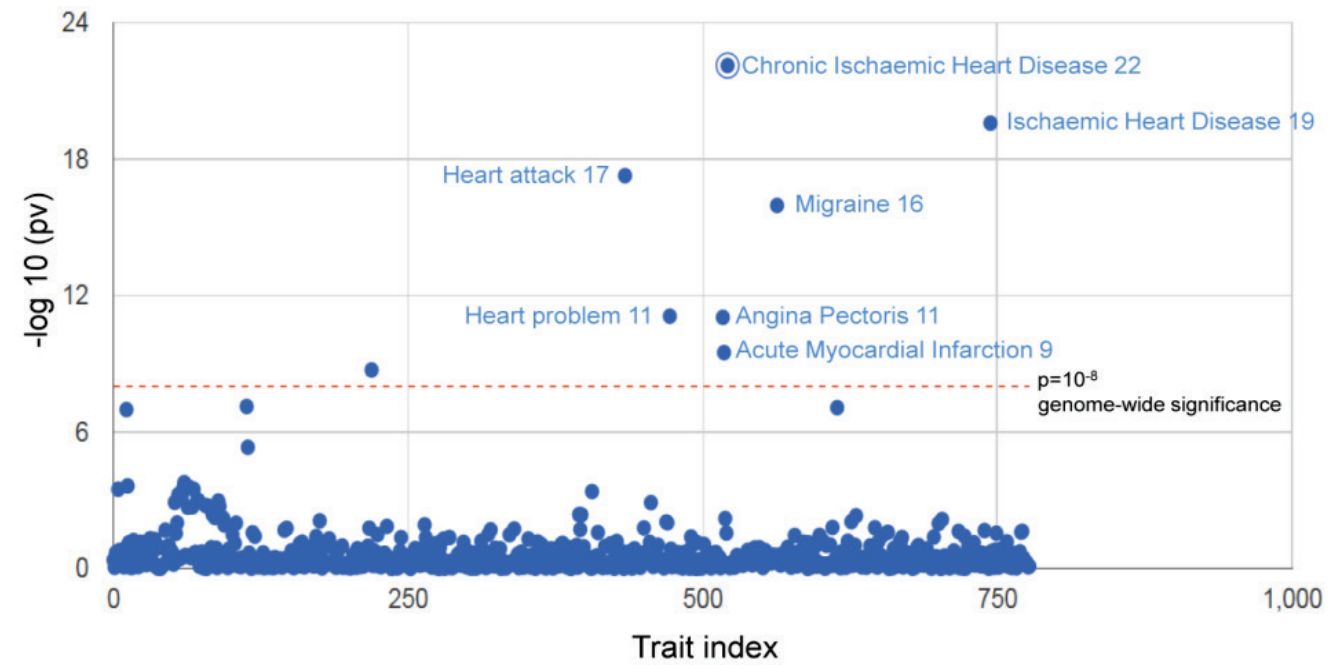

Fig. 6. Graph showing a high genome-wide significant correlation $\left(P<10^{-8}\right.$, indicated by dashed line) between the SNP rs9349379 and vascular conditions including chronic and ischemic heart disease and heart attack. Numbers adjacent to the trait indicate the significance. Vertical axis shows - log10 probability value (pv) versus the trait index. Data are from UK Biobank (Sudlow et al. 2015).

healthy individuals there was significant association between G genotype with, as predicted, plasma levels $20 \%$ higher. Importantly this minor $\mathrm{G} / \mathrm{G}$ allele is common, with a $38 \%$ frequency in the 1000 Genomes Project Consortium database (Auton et al. 2015). The genome studies suggest individuals with this minor allele SNP G/G would be predicted to have a lifetime exposure to significantly elevated levels of ET-1 and implying that in coronary artery disease leading to atherosclerosis and calcification, the ET signaling pathway would be upregulated. New imaging techniques (Irkle et al. 2015) that identify active unstable atherosclerosis using positron emission tomography provide the mechanism for testing the efficacy of ET receptor antagonism in patients with the genotype for the $\mathrm{G} / \mathrm{G}$ allele compared with $\mathrm{A} / \mathrm{A}$.

In patients with atherosclerosis, a number of studies show a consistent pattern of increased plasma levels of ET (Davenport and Maguire 2006). Tissue levels of ET-1 mRNA (Winkles et al. 1993) as well as both the mature peptide and big ET-1 were significantly 
increased within the wall of human vessels containing atherosclerotic lesions (raised plaque, Fig. 7A, Bacon et al. 1996). Gupta et al. (2017) measured elevated levels of big ET-1 rather than the mature peptide. About one in four big ET-1 molecules synthesized within endothelial cells escapes conversion within the endothelium and is released to circulate in the plasma. In humans, infusion of big ET-1 into volunteers causes pronounced vasoconstriction by local conversion to ET-1, by a phosphoramidon sensitive ECE localized to the smooth muscle (Plumpton et al. 1996). In human coronary arteries with atherosclerotic lesion target receptors expressed by contractile smooth muscle remain unaltered although proliferating smooth muscle cells within the lesion display few receptors (Fig. 7B). In diseased coronary arteries denuded of endothelium, smooth muscle ECE activity is upregulated, increasing the amount of ET-1 synthesized from big ET-1 at the site of the lesion (Fig. 7C). In agreement with the increased contractile response to big ET-1, there was a corresponding increase in mature ET formed in the bathing medium (Fig. 7D, compared with non-diseased arteries) (Maguire and
Davenport 1998). Animal models can provide insight into the long-term exposure to ET-1. In mice, endothelial ET-1 overexpression (by an order of magnitude) caused sustained blood pressure elevation and vascular and renal injury via $\mathrm{ET}_{\mathrm{A}}$ receptors (Coelho et al. 2018).

The study by Gupta et al. (2017) combined with the results described above showing ET-1 is a powerful, long lasting constrictor of human coronary arteries through the $\mathrm{ET}_{\mathrm{A}}$ receptor, contributing to vasospasm and angina in patients with coronary artery disease support the suggestion that those with the $G / G$ allele would have higher ET-1 levels and therefore enhanced vasoconstriction. Patients with this $\mathrm{G} / \mathrm{G}$ allele are predicted to be more responsive to $\mathrm{ET}_{\mathrm{A}}$ antagonism than those with A/A or A/G. Conversely, Gupta et al. (2017) identified four vascular disease where the minor allele G/G and elevated big ET-1 is alternatively associated with a reduced risk of cervical dissection, migraine headache, fibromuscular dysplasia (three diseases that co-occur epidemiologically), and hypertension and in which a lifetime of elevated ET-1 levels may be beneficial.
A
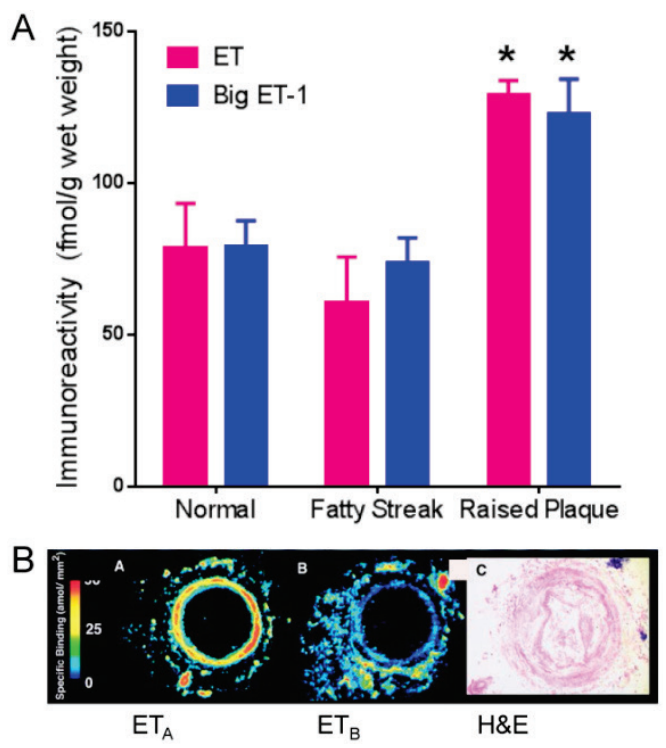

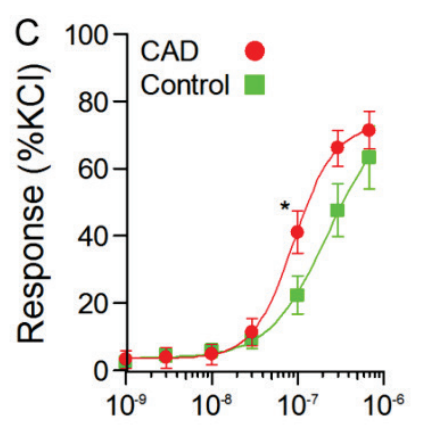

Big ET-1 [M]

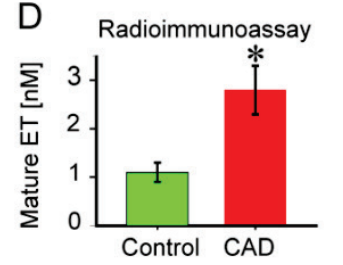

Fig. 7. Upregulation of the ET-1 pathway in human atherosclerosis. (A) Tissue levels of both ET-1 and big ET-1 were increased in coronary arteries with developed atherosclerosis (raised plaque) compared with healthy vessels or those with fatty streaks (early atherosclerosis). (B) Target receptors expressed by contractile smooth muscle remain unaltered although proliferating smooth muscle cells within the lesion display few receptors. (C) In human coronary arteries with atherosclerotic lesion denuded of endothelium, smooth muscle ECE activity was upregulated resulting in increased responses to big ET-1 with (D) a corresponding increase in mature ET formed in the bathing medium compared with non-diseased arteries. Data from Maguire et al. (1997), Bacon et al. (1996).
The causes of migraine headache continues to be debated as it is a complex, multisystem disorder, and changes in vascular function, particularly unwanted vasodilatation, as a cause has been challenged (Brennan and Charles 2017). However, reduced levels of ET-1 to oppose vasodilatation is a plausible hypothesis to test in patients with the $\mathrm{G} / \mathrm{G}$ allele. Pial arteries, the targets for meningeal vasodilation causing headache, for example, are exquisitely sensitive to ET-1 (Pierre and Davenport 1999). A link to ET-1 and the pathophysiology of cervical dissection or fibromuscular dysplasia has not been established but this new direction for research should be explored. The association of the $\mathrm{G} / \mathrm{G}$ allele with lower systolic blood pressure is counter intuitive but in agreement a negative correlation between systolic blood pressure and plasma ET levels has previously been reported in patients with hypertension (Davenport et al. 1990). This is consistent with ET-1 acting in an autocrine/paracrine manner on endothelial cell $\mathrm{ET}_{\mathrm{B}}$ receptors to release vasodilators to reduce constrictor 
$\mathrm{ET}_{\mathrm{A}}$ responses (Fig. 4) and is a possible mechanism for synergy between $\mathrm{ET}_{\mathrm{A}}$ selective ligands and PDE5 inhibitors.

\section{Conflict of Interest}

There is no conflict of interest.

\section{Acknowledgements}

This work was supported by the Wellcome Trust 107715/Z/15/Z, Medical Research Council MC_PC_14116 and in part, by the National Institute for
Health Research Cambridge Biomedical Research Center and the Pulmonary Hypertension Association UK.

\section{Abbreviations}

ECE, endothelin converting enzyme; ERKs, extracellular signal-regulated kinases; ET-1, endothelin-1; ET-2, endothelin-2; ET-3, endothelin-3; MABs, monoclonal antibodies; MAPK, MAP-kinase; PAH, pulmonary arterial hypertension; PDE, phosphodiesterase; SNP, single nucleotide polymorphism.

\section{References}

ALLARD B, WIJKHUISEN A, BORRULL A, DESHAYES F, PRIAM F, LAMOURETTE P, DUCANCEL F, BOQUET D, COURAUD JY: Generation and characterization of rendomab-B1, a monoclonal antibody displaying potent and specific antagonism of the human endothelin B receptor. MAbs 5: 56-69, 2013.

ASUNDI J, REED C, ARCA J, MCCUTCHEON K, FERRANDO R, CLARK S, LUIS E, TIEN J, FIRESTEIN R, POLAKIS P: An antibody-drug conjugate targeting the endothelin B receptor for the treatment of melanoma. Clin Cancer Res 17: 965-975, 2011.

AUTON A, BROOKS LD, DURBIN RM, GARRISON EP, KANG HM, KORBEL JO, MARCHINI JL, MCCARTHY S, MCVEAN GA, ABECASIS GR: A global reference for human genetic variation. Nature 526: 68-74, 2015.

BACON CR, CARY NR, DAVENPORT AP: Endothelin peptide and receptors in human atherosclerotic coronary artery and aorta. Circ Res 79: 794-801, 1996.

BAGNATO A, ROSANÒ L, SPINELLA F, Di CASTRO V, TECCE R, NATALI PG: Endothelin B receptor blockade inhibits dynamics of cell interactions and communications in melanoma cell progression. Cancer Res 64: 1436-1443, 2004.

BITTNER M, MELTZER P, CHEN Y, JIANG Y, SEFTOR E, HENDRIX M, RADMACHER M, SIMON R, YAKHINI Z, BEN-DOR A, SAMPAS N, DOUGHERTY E, WANG E, MARINCOLA F, GOODEN C, LUEDERS J, GLATFELTER A, POLLOCK P, CARPTEN J, GILLANDERS E, LEJA D, DIETRICH K, BEAUDRY C, BERENS M, ALBERTS D, SONDAK V: Molecular classification of cutaneous malignant melanoma by gene expression profiling. Nature 406: 536-540, 2000.

BLANDIN V, VIGNE P, BREITTMAYER JP, FRELIN C: Allosteric inhibition of endothelin ETA receptors by 3, 5-dibromosalicylic acid. Mol Pharmacol 58: 1461-1469, 2000.

BORRULL A, ALLARD B, WIJKHUISEN A, HERBET A, LAMOURETTE P, BIROUK W, LEIBER D, TANFIN Z, DUCANCEL F, BOQUET D, COURAUD JY, ROBIN P: Rendomab B4, a monoclonal antibody that discriminates the human endothelin $\mathrm{B}$ receptor of melanoma cells and inhibits their migration. MAbs $\mathbf{8}$ : 1371-1385, 2016.

BRAME AL, MAGUIRE JJ, YANG P, DYSON A, TORELLA R, CHERIYAN J, SINGER M, GLEN RC, WILKINSON IB, DAVENPORT AP: Design, characterization, and first-in-human study of the vascular actions of a novel biased apelin receptor agonist. Hypertension 65: 834-840, 2015.

BREMNES T, PAASCHE JD, MEHLUM A, SANDBERG C, BREMNES B, ATTRAMADAL H: Regulation and intracellular trafficking pathways of the endothelin receptors. J Biol Chem 275: 17596-17604, 2000.

BRENNAN KC, CHARLES A: An update on the blood vessel in migraine. Curr Opin Neurol 23: 266-274, 2010.

BRIYAL S, SHEPARD C, GULATI A: Endothelin receptor type B agonist, IRL-1620, prevents beta amyloid (Abeta) induced oxidative stress and cognitive impairment in normal and diabetic rats. Pharmacol Biochem Behav 120: 65-72, 2014. 
BRIYAL S, NGUYEN C, LEONARD M, GULATI A: Stimulation of endothelin B receptors by IRL-1620 decreases the progression of Alzheimer's disease. Neuroscience 301: 1-11, 2015.

CARR R 3RD, BENOVIC JL: From biased signalling to polypharmacology: unlocking unique intracellular signalling using pepducins. Biochem Soc Trans 44: 555-561, 2016.

CIANFROCCA R, TOCCI P, SEMPRUCCI E, SPINELlA F, Di CASTRO V, BAGNATO A, ROSANÒ L: beta-arrestin 1 is required for endothelin-1-induced NF-kappaB activation in ovarian cancer cells. Life Sci 118: 179-184, 2014.

CLOZEL M: Endothelin research and the discovery of macitentan for the treatment of pulmonary arterial hypertension. Am J Physiol Regul Integr Comp Physiol 311: R721-R726, 2016.

COELHO SC, BERILLO O, CAILLON A, OUERD S, FRAULOB-AQUINO JC, BARHOUMI T, OFFERMANNS S, PARADIS P, SCHIFFRIN EL: Three-month endothelial human endothelin-1 overexpression causes blood pressure elevation and vascular and kidney injury. Hypertension 71: 208-216, 2018.

CZOPEK A, MOORHOUSE R, WEBB DJ, DHAUN N: Therapeutic potential of endothelin receptor antagonism in kidney disease. Am J Physiol Regul Integr Comp Physiol 310: R388-R397, 2016.

DAVENPORT AP: International Union of Pharmacology. XXIX. Update on endothelin receptor nomenclature. Pharmacol Rev 54: 219-226, 2002.

DAVENPORT AP, MAGUIRE JJ: Endothelin. Handb Exp Pharmacol 176: 295-329, 2006.

DAVENPORT AP, ASHBY MJ, EASTON P, ELLA S, BEDFORD J, DICKERSON C, NUNEZ DJ, CAPPER SJ, BROWN MJ: A sensitive radioimmunoassay measuring endothelin-like immunoreactivity in human plasma: comparison of levels in patients with essential hypertension and normotensive control subjects. Clin Sci (Lond) 78: 261-264, 1990.

DAVENPORT AP, HYNDMAN KA, DHAUN N, SOUTHAN C, KOHAN DE, POLLOCK JS, POLLOCK DM, WEBB DJ, MAGUIRE JJ: Endothelin. Pharmacol Rev 68: 357-418, 2016.

ECKMAN EA, REED DK, ECKMAN CB: Degradation of the Alzheimer's amyloid beta peptide by endothelinconverting enzyme. J Biol Chem 276: 24540-24548, 2001.

ECKMAN EA, WATSON M, MARLOW L, SAMBAMURTI K, ECKMAN CB: Alzheimer's disease beta-amyloid peptide is increased in mice deficient in endothelin-converting enzyme. J Biol Chem 278: 2081-2084, 2003.

ECKMAN EA, ADAMS SK, TROENDLE FJ, STODOLA BA, KAHN MA, FAUQ AH, XIAO HD, BERNSTEIN KE, ECKMAN CB: Regulation of steady-state beta-amyloid levels in the brain by neprilysin and endothelinconverting enzyme but not angiotensin-converting enzyme. J Biol Chem 281: 30471-30478, 2006.

FUKURODA T, FUJIKAWA T, OZAKI S, ISHIKAWA K, YANO M, NISHIKIBE M: Clearance of circulating endothelin-1 by ETB receptors in rats. Biochem Biophys Res Commun 199: 1461-1465, 1994.

GALIE N, BARBERA JA, FROST AE, GHOFRANI HA, HOEPER MM, MCLAUGHLIN VV, PEACOCK AJ, SIMONNEAU G, VACHIERY JL, GRUNIG E, OUDIZ RJ, VONK-NOORDEGRAAF A, WHITE RJ, BLAIR C, GILLIES H, MILLER KL, HARRIS JH, LANGLEY J, RUBIN LJ: Initial use of ambrisentan plus tadalafil in pulmonary arterial hypertension. N Engl J Med 373: 834-844, 2015.

GASIC S, WAGNER OF, VIERHAPPER H, NOWOTNY P, WALDHAUSL W: Regional hemodynamic effects and clearance of endothelin-1 in humans: renal and peripheral tissues may contribute to the overall disposal of the peptide. J Cardiovasc Pharmacol 19: 176-180, 1992.

GREEN DS, RUPASINGHE C, WARBURTON R, WILSON JL, SALLUM CO, TAYLOR L, YATAWARA A, MIERKE D, POLGAR P, HILL N: A cell permeable peptide targeting the intracellular loop 2 of endothelin B receptor reduces pulmonary hypertension in a hypoxic rat model. PLoS One 8: e81309, 2013.

GULATI A: Endothelin receptors, mitochondria and neurogenesis in cerebral ischemia. Curr Neuropharmacol 14: 619-626, 2016.

GULATI S, BRIYAL S, JONES S, BHALLA S, GULATI A: Attenuation of opioid tolerance by ETB receptor agonist, IRL-1620, is independent of an accompanied decrease in nerve growth factor in mice. Heliyon 3: e00317, 2017. 
GUPTA RM, HADAYA J, TREHAN A, ZEKAVAT SM, ROSELLI C, KLARIN D, EMDIN CA, HILVERING CRE, BIANCHI V, MUELLER C, KHERA AV, RYAN RJH, ENGREITZ JM, ISSNER R, SHORESH N, EPSTEIN CB, DE LAAT W, BROWN JD, SCHNABEL RB, BERNSTEIN BE, KATHIRESAN S: A genetic variant associated with five vascular diseases is a distal regulator of endothelin-1 gene expression. Cell 170: 522-533.e515, 2017.

GURBEL PA, BLIDEN KP, TURNER SE, TANTRY US, GESHEFF MG, BARR TP, COVIC L, KULIOPULOS A: Cell-penetrating pepducin therapy targeting PAR1 in subjects with coronary artery disease. Arterioscler Thromb Vasc Biol 36: 189-197, 2016.

HARLAND SP, KUC RE, PICKARD JD, DAVENPORT AP: Expression of endothelin(A) receptors in human gliomas and meningiomas, with high affinity for the selective antagonist PD156707. Neurosurgery 43: 890-898, 1998.

HERBET A, COSTA N, LEVENTOUX N, MABONDZO1 A, BORRULL A, HUGNOT J-P, BOQUET D: Antibodies targeting human endothelin-1 receptors reveal different conformational states in cancer cells. Physiol Res $\mathbf{6 7}$ (Suppl 1): S257-S264, 2018.

HOEPER MM, MCLAUGHLIN VV, BARBERA JA, FROST AE, GHOFRANI HA, PEACOCK AJ, SIMONNEAU G, ROSENKRANZ S, OUDIZ RJ, WHITE RJ, MILLER KL, LANGLEY J, HARRIS JHN, BLAIR C, RUBIN LJ, VACHIERY JL: Initial combination therapy with ambrisentan and tadalafil and mortality in patients with pulmonary arterial hypertension: a secondary analysis of the results from the randomised, controlled AMBITION study. Lancet Respir Med 4: 894-901, 2016.

HOUDE M, DESBIENS L, D'ORLEANS-JUSTE P: Endothelin-1: biosynthesis, signaling and vasoreactivity. $A d v$ Pharmacol 77: 143-175, 2016.

HUTCHINGS CJ, KOGLIN M, OLSON WC, MARSHALL FH: Opportunities for therapeutic antibodies directed at G-protein-coupled receptors. Nat Rev Drug Discov 16: 787-810, 2017.

IGLARZ M, BINKERT C, MORRISON K, FISCHLI W, GATFIELD J, TREIBER A, WELLER T, BOLLI MH, BOSS C, BUCHMANN S, CAPELETO B, HESS P, QIU C, CLOZEL M: Pharmacology of macitentan, an orally active tissue-targeting dual endothelin receptor antagonist. $J$ Pharmacol Exp Ther 327: 736-745, 2008.

IRKLE A, VESEY AT, LEWIS DY, SKEPPER JN, BIRD JL, DWECK MR, JOSHI FR, GALLAGHER FA, WARBURTON EA, BENNETT MR, BRINDLE KM, NEWBY DE, RUDD JH, DAVENPORT AP: Identifying active vascular microcalcification by ${ }^{(18)} \mathrm{F}$-sodium fluoride positron emission tomography. Nat Commun 6: 7495, 2015.

JOHNSTROM P, FRYER TD, RICHARDS HK, HARRIS NG, BARRET O, CLARK JC, PICKARD JD, DAVENPORT AP: Positron emission tomography using ${ }^{18} \mathrm{~F}$-labelled endothelin-1 reveals prevention of binding to cardiac receptors owing to tissue-specific clearance by $\mathrm{ET}_{\mathrm{B}}$ receptors in vivo. Br J Pharmacol 144: 115-122, 2005.

JOSHI MD, OESTERLING BM, WU C, GWIZDZ N, PAIS G, BRIYAL S, GULATI A: Evaluation of liposomal nanocarriers loaded with ETB receptor agonist, IRL-1620, using cell-based assays. Neuroscience 312: 141-152, 2016.

KIM R, CHIOREAN EG, AMIN M, ROCHA-LIMA CMS, GANDHI J, HARRIS WP, SONG T, PORTNOY D: Phase 2 study of combination SPI-1620 with docetaxel as second-line advanced biliary tract cancer treatment. Br J Cancer 117: 189-194, 2017.

KOMERS R, GIPSON DS, NELSON P, ADLER S, SRIVASTAVA T, DEREBAIL VK, MEYERS KE, PERGOLA P, MACNALLY ME, HUNT JL, SHIH A, TRACHTMAN H: Efficacy and safety of sparsentan compared with irbesartan in patients with primary focal segmental glomerulosclerosis: randomized, controlled trial design (DUET). Kidney Int Rep 2: 654-664, 2017.

KUC RE, DAVENPORT AP: Comparison of $\mathrm{ET}_{\mathrm{A}}$ and $\mathrm{ET}_{\mathrm{B}}$ receptor distribution visualised by radioligand binding versus immunocytochemical localisation using sub-type selective antisera. $J$ Cardiovasc Pharmacol 44 (Suppl 1): S224-S226, 2004.

KUNTZ M, LEIVA-JUAREZ MM, LUTHRA S: Systematic review of randomized controlled trials of endothelin receptor antagonists for pulmonary arterial hypertension. Lung 194: 723-732, 2016. 
LAHAV R: Endothelin receptor B is required for the expansion of melanocyte precursors and malignant melanoma. Int J Dev Biol 49: 173-180, 2005.

LEE JA, ELLIOTT JD, SUTIPHONG JA, FRIESEN WJ, OHLSTEIN EH, STADEL JM, GLEASON JG, PEISHOFF CE: Tyr-129 is important to the peptide ligand affinity and selectivity of human endothelin type A receptor. Proc Natl Acad Sci U S A 91: 7164-7168, 1994.

LEONARD MG, GULATI A: Endothelin B receptor agonist, IRL-1620, enhances angiogenesis and neurogenesis following cerebral ischemia in rats. Brain Res 1528: 28-41, 2013.

LEONARD MG, BRIYAL S, GULATI A: Endothelin B receptor agonist, IRL-1620, reduces neurological damage following permanent middle cerebral artery occlusion in rats. Brain Res 1420: 48-58, 2011.

LEONARD MG, BRIYAL S, GULATI A: Endothelin B receptor agonist, IRL-1620, provides long-term neuroprotection in cerebral ischemia in rats. Brain Res 1464: 14-23, 2012.

LIANG F, YANG S, YAO L, BELARDINELLI L, SHRYOCK J: Ambrisentan and tadalafil synergistically relax endothelin-induced contraction of rat pulmonary arteries. Hypertension 59: 705-711, 2012.

MAGUIRE JJ: Evidence for biased agonists and antagonists at the endothelin receptors. Life Sci 159: 30-33, 2016.

MAGUIRE JJ, DAVENPORT AP: Increased response to big endothelin-1 in atherosclerotic human coronary artery: functional evidence for up-regulation of endothelin-converting enzyme activity in disease. Br J Pharmacol 125: 238-240, 1998.

MAGUIRE JJ, DAVENPORT AP: Endothelin@25 - new agonists, antagonists, inhibitors and emerging research frontiers: IUPHAR Review 12. Br J Pharmacol 171: 5555-5572, 2014.

MAGUIRE JJ, KUC RE, ROUS BA, DAVENPORT AP: Failure of BQ123, a more potent antagonist of sarafotoxin $6 \mathrm{~b}$ than of endothelin-1, to distinguish between these agonists in binding experiments. Br J Pharmacol 118: 335-342, 1996.

MAGUIRE JJ, KUC RE, DAVENPORT AP: Defining the affinity and receptor sub-type selectivity of four classes of endothelin antagonists in clinically relevant human cardiovascular tissues. Life Sci 91: 681-686, 2012.

MERCURIO V, MUKHERJEE M, TEDFORD RJ, ZAMANIAN RT, KHAIR RM, SATO T, MINAI OA, TORRES F, GIRGIS RE, CHIN K, DAMICO R, KOLB TM, MATHAI SC, HASSOUN PM: improvement in right ventricular strain with ambrisentan and tadalafil upfront therapy in scleroderma pulmonary arterial hypertension. Am J Respir Crit Care Med 197: 388-391, 2018.

MURUGESAN N, GU Z, FADNIS L, TELLEW JE, BASKA RA, YANG Y, BEYER SM, MONSHIZADEGAN H, DICKINSON KE, VALENTINE MT, HUMPHREYS WG, LAN SJ, EWING WR, CARLSON KE, KOWALA MC, ZAHLER R, MACOR JE: Dual angiotensin II and endothelin A receptor antagonists: synthesis of 2'-substituted N-3-isoxazolyl biphenylsulfonamides with improved potency and pharmacokinetics. J Med Chem 48: 171-179, 2005.

PACHECO-QUINTO J, ECKMAN EA: Endothelin-converting enzymes degrade intracellular beta-amyloid produced within the endosomal/lysosomal pathway and autophagosomes. J Biol Chem 288: 5606-5615, 2013.

PÁNDY-SZEKERES G, MUNK C, TSONKOV TM, MORDALSKI S, HARPSØE K, HAUSER AS, BOJARSKI AJ, GLORIAM DE: GPCRdb in 2018: adding GPCR structure models and ligands. Nucleic Acids Res 46 (D1): D440-D446, 2018.

PIERRE LN, DAVENPORT AP: Blockade and reversal of endothelin-induced constriction in pial arteries from human brain. Stroke 30: 638-643, 1999.

PLUMPTON C, FERRO CJ, HAYNES WG, WEBB DJ, DAVENPORT AP: The increase in human plasma immunoreactive endothelin but not big endothelin-1 or its C-terminal fragment induced by systemic administration of the endothelin antagonist TAK-044. Br J Pharmacol 119: 311-314, 1996.

READ C, FITZPATRICK CM, YANG P, KUC RE, MAGUIRE JJ, GLEN RC, FOSTER RE, DAVENPORT AP: Cardiac action of the first $G$ protein biased small molecule apelin agonist. Biochem Pharmacol 116: 63-72, 2016.

ROSANÒ L, BAGNATO A: beta-arrestin1 at the cross-road of endothelin-1 signaling in cancer. $J$ Exp Clin Cancer Res 35: 121, 2016a. 
ROSANÒ L, BAGNATO A: Endothelin therapeutics in cancer: Where are we? Am J Physiol Regul Integr Comp Physiol 310: R469-R475, 2016b.

ROSANÒ L, CIANFROCCA R, TOCCI P, SPINELLA F, DI CASTRO V, CAPRARA V, SEMPRUCCI E, FERRANDINA G, NATALI PG, BAGNATO A: Endothelin A receptor/beta-arrestin signaling to the Wnt pathway renders ovarian cancer cells resistant to chemotherapy. Cancer Res 74: 7453-7464, 2014.

RUSSELL FD, DAVENPORT AP: Evidence for intracellular endothelin-converting enzyme-2 expression in cultured human vascular endothelial cells. Circ Res 84: 891-896, 1999.

RUSSELL FD, SKEPPER JN, DAVENPORT AP: Human endothelial cell storage granules: a novel intracellular site for isoforms of the endothelin-converting enzyme. Circ Res 83: 314-321, 1998.

SAWAKI M, WADA A, TSUTAMOTO T, OHNISHI M, FUJII M, MATSUMOTO T, KINOSHITA M: Chronic effects of an orally active selective endothelin-B-receptor antagonist in experimental congestive heart failure. J Cardiovasc Pharmacol 36 (Suppl 1): S323-S326, 2000.

SHIHOYA W, NISHIZAWA T, OKUTA A, TANI K, DOHMAE N, FUJIYOSHI Y, NUREKI O, DOI T: Activation mechanism of endothelin ETB receptor by endothelin-1. Nature 537: 363-368, 2016.

SHIHOYA W, NISHIZAWA T, YAMASHITA K, INOUE A, HIRATA K, KADJI FMN, OKUTA A, TANI K, AOKI J, FUJIYOSHI Y, DOI T, NUREKI O: X-ray structures of endothelin ETB receptor bound to clinical antagonist bosentan and its analog. Nat Struct Mol Biol 24: 758-764, 2017.

SIDHARTA PN, VAN GIERSBERGEN PL, HALABI A, DINGEMANSE J: Macitentan: entry-into-humans study with a new endothelin receptor antagonist. Eur J Clin Pharmacol 67: 977-984, 2011.

SIDHARTA PN, KRAHENBUHL S, DINGEMANSE J: Pharmacokinetic and pharmacodynamic evaluation of macitentan, a novel endothelin receptor antagonist for the treatment of pulmonary arterial hypertension. Expert Opin Drug Metab Toxicol 11: 437-449, 2015.

SINGLA N, MINKOWITZ HS, SOERGEL DG, BURT DA, SUBACH RA, SALAMEA MY, FOSSLER MJ, SKOBIERANDA F: A randomized, Phase IIb study investigating oliceridine (TRV130), a novel microreceptor G-protein pathway selective (mu-GPS) modulator, for the management of moderate to severe acute pain following abdominoplasty. J Pain Res 10: 2413-2424, 2017.

SUDLOW C, GALLACHER J, ALLEN N, BERAL V, BURTON P, DANESH J, DOWNEY P, ELLIOTT P, GREEN J, LANDRAY M, LIU B, MATTHEWS P, ONG G, PELL J, SILMAN A, YOUNG A, SPROSEN T, PEAKMAN T, COLLINS R: UK biobank: an open access resource for identifying the causes of a wide range of complex diseases of middle and old age. PLoS Med 12: e1001779, 2015.

TAKAI M, UMEMURA I, YAMASAKI K, WATAKABE T, FUJITANI Y, ODA K, URADE Y, INUI T, YAMAMURA T, OKADA T: A potent and specific agonist, Suc-[Glu9,Ala11,15]-endothelin-1(8-21), IRL 1620, for the ETB receptor. Biochem Biophys Res Commun 184: 953-959, 1992.

TALBODEC A, BERKANE N, BLANDIN V, BREITTMAYER JP, FERRARI E, FRELIN C, VIGNE P: Aspirin and sodium salicylate inhibit endothelin ETA receptors by an allosteric type of mechanism. Mol Pharmacol 57: 797-804, 2000.

TRESSEL SL, KOUKOS G, TCHERNYCHEV B, JACQUES SL, COVIC L, KULIOPULOS A: Pharmacology, biodistribution, and efficacy of GPCR-based pepducins in disease models. Methods Mol Biol 683: 259-275, 2011.

WANG J, HANADA K, STAUS DP, MAKARA MA, DAHAL GR, CHEN Q, AHLES A, ENGELHARDT S, ROCKMAN HA: Galphai is required for carvedilol-induced beta1 adrenergic receptor beta-arrestin biased signaling. Nat Commun 8: 1706, 2017.

WARNER TD, ALLCOCK GH, VANE JR: Reversal of established responses to endothelin-1 in vivo and in vitro by the endothelin receptor antagonists, BQ-123 and PD 145065. Br J Pharmacol 112: 207-213, 1994.

WINKLES JA, ALBERTS GF, BROGI E, LIBBY P: Endothelin-1 and endothelin receptor mRNA expression in normal and atherosclerotic human arteries. Biochem Biophys Res Commun 191: 1081-1088, 1993. 
WOUTERS J, HUNGER RE, GARROD T, DUBUIS B, HUNZIKER T, VAN DEN OORD JJ, LAHAV-LE COUTRE R: First-in-human proof-of-concept study: intralesional administration of BQ788, an endothelin receptor B antagonist, to melanoma skin metastases. Oncologist 20: 1121-1122, 2015.

YANG P, READ C, KUC RE, BUONINCONTRI G, SOUTHWOOD M, TORELLA R, UPTON PD, CROSBY A, SAWIAK SJ, CARPENTER TA, GLEN RC, MORRELL NW, MAGUIRE JJ, DAVENPORT AP: Elabela/toddler is an endogenous agonist of the apelin APJ receptor in the adult cardiovascular system, and exogenous administration of the peptide compensates for the downregulation of its expression in pulmonary arterial hypertension. Circulation 135: 1160-1173, 2017a.

YANG P, CROSBY A, SOUTHWOOD M, MAGUIRE JJ, BUONINCONTRI G, READ C, UPTON PD, KUC RE, SAWIAK SJ, MORRELL NW, DAVENPORT AP: The novel biased apelin receptor agonist MM07 attenuates pulmonary vascular remodeling in monocrotaline-induced pulmonary arterial hypertension. Circulation 136: A17882, 2017b. 